\title{
HVMANITAS
}

\section{Greek vases in Portugal: a new supplement}

Autor(es): $\quad$ Pereira, Maria Helena da Rocha

Publicado por: Faculdade de Letras da Universidade de Coimbra, Instituto de Estudos

URL

persistente: URI:http://hdl.handle.net/10316.2/27906

DOI: $\quad$ DOI:http://dx.doi.org/10.14195/2183-1718_60_1

Accessed : $\quad$ 26-Apr-2023 09:23:46

A navegação consulta e descarregamento dos títulos inseridos nas Bibliotecas Digitais UC Digitalis, UC Pombalina e UC Impactum, pressupõem a aceitação plena e sem reservas dos Termos e Condições de Uso destas Bibliotecas Digitais, disponíveis em https://digitalis.uc.pt/pt-pt/termos.

Conforme exposto nos referidos Termos e Condições de Uso, o descarregamento de títulos de acesso restrito requer uma licença válida de autorização devendo o utilizador aceder ao(s) documento(s) a partir de um endereço de IP da instituição detentora da supramencionada licença.

Ao utilizador é apenas permitido o descarregamento para uso pessoal, pelo que o emprego do(s) título(s) descarregado(s) para outro fim, designadamente comercial, carece de autorização do respetivo autor ou editor da obra.

Na medida em que todas as obras da UC Digitalis se encontram protegidas pelo Código do Direito de Autor e Direitos Conexos e demais legislação aplicável, toda a cópia, parcial ou total, deste documento, nos casos em que é legalmente admitida, deverá conter ou fazer-se acompanhar por este aviso. 
humanitas

\section{Vol. LX}

IMPRENSA DA UNIVERSIDADE DE COIMBRA

COIMBRA UNIVERSITY PRESS 


\title{
GREEK VASES IN PORTUGAL A NEW SUPPLEMENT
}

\author{
Maria Helena da Rocha Pereira \\ Universidade de Coimbra \\ classic@fl.uc.pt
}

\begin{abstract}
Resumo
A hydria ática de figuras negras publicada pela autora em Humanitas 1959 e posteriormente incluída no seu livro Greek Vases in Portugal (1962) foi depois restaurada pelo Dr. Dietrich von Bothmer em pessoa. Traça-se agora a comparação entre o seu estado anterior e o actual, bem como com outros tratamentos do mesmo mito.
\end{abstract}

Palavras-chave: Vasos gregos, Troilo, Aquiles.

\section{Abstract}

The Attic black figure hydria published by the author in Humanitas 1959 and later included in her book Greek Vases in Portugal (1962) was later restored by Dr. Dietrich von Bothmer himself. A comparison is now drawn between its former and present state as well as to other treatments of the same myth.

Keywords: Greek Vases, Troilos, Achilles.

When I first published in this journal ${ }^{1}$ an Attic black figure hydria belonging to a private collection in Lisbon, the vase already had an adventurous story behind it, and the same happened when I included it in

${ }^{1}$ Humanitas XI-XII (1959) 18-20. 
my book Greek Vases in Portugal (1962: 41-47). But now, as I have gathered more information about the vase, I believe it may be appropriate to put together a summary of the previous data, in order to compare them with the results of its having been cleaned by the most expert hands one could wish for.

Formerly a part of Sir Francis Cook's collection, Monserrate Palace, Sintra (Lisbon), the vase is a hydria of Type I, of the last quarter of the sixth century B.C. (Richter-Milne 1935: figs. 78-79). It represents Achilles and Troilos, and a chariot-scene on the shoulder. Unfortunately, the painting had been much restored, so that apparently only the horses on the left had been preserved in their original state. The vase had been included in the Leagros group by Prof. Sir John Beazley ( $A B V: 362,36$ ) with the warning 'restored'. By that time, it was considered to be lost. Since the publication of my above mentioned paper, Brommer (1960: $268,7)$ included it in the second edition of his Vasenlisten.

Given all this, it might seem that the vase had an academic interest only. But now there are reasons that make it interesting to recollect its curious story up to its present state.

As far as we now, the vase belonged first to Campanari, then to Rogers, in whose collection it was numbered $372^{2}$, and thirdly to Harding. It was published by Jahn (1845: pl. 2) and by Gerhard (1843: pls. 5 and 6) and also described by Secondiano Campanari (1834: 234-238), who gives a clear interpretation of the scene, taking the figure on the altar as being that of Apollo, whose name he read in the corner.

Although Campanari (1834: 238) already spoke of restoration, Gerhard, who knew the vase in apparently the same condition, gives more precise information on the inscriptions, which are important ${ }^{3}$ :

"Das Gefäss ist ergänzt, dargestellt dass, der von Herrn Rogers mir gestatteten Prüfung gemäss, statt der Inschrift $A \Pi O \Lambda \Lambda \Omega N$ füglich TPOI $\triangle O \Sigma$ ursprünglich sein kann; von den übrigen Inschriften, die unangerührt blieben, mag $A X I \Lambda \Lambda E Y \Sigma$ beglaubt sein, dagegen wir uns erlauben, die

${ }^{2}$ It has been described in the sale catalogue of the Samuel Rogers' Collection, Christie and Manson, April 28th 1856 ff., p. 25 (I owe this reference to Dr. Dietrich von Bothmer).

${ }^{3}$ In this as well as in the following inscriptions, archaic Greek letters have been replaced by classic ones, owing to printing difficulties. 


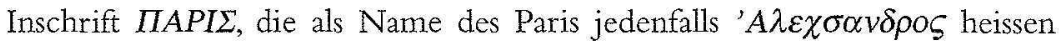
müsste, bis zur Nachweisung ihrer Echtheit für untergeschoben zu halten. Dieses vorausgesetzt, ist der von Achill auf Apollo's Altar an Troilos verübte Frevel unverkennbar; aus dem skäischen Thor kommt rechterseits Hektor mit später Hülfe herbei, während linkerseits zugleich mit Achill's Wagen vielleicht auch Beistand der Griechischen vermutet werden darf."

A similar, but more accurate, description has been provided by Gurlitt (1868: 86), when he saw the same vase at Monserrate palace. Here I only give a transcription of its most relevant parts:

"Zunächst die Vordertheile von vier Pferden mit weissem Zaumwerk. Es folgt eine grosse Kriegergestalt, welche durch eine Inschrift links vom Kopfe als $A X I \Lambda \Lambda E Y \Sigma$ bezeichnet ist. Auf dem Kopfe, von dem reiche Locken auf die rechte Schulter herabwellen, trägt er einen grosser Helm mit grossem, braunem Kamm und langem Helmschweif, der Brustharnisch ist weiss, ebenso die braugeränderten Beinschienen. Der linke Fuss tritt in starker Biegung auf einen Mauerabsatz, welcher aus zwei Lagen Quadersteinen gebildet ist. Seine hochgehobene Linke hat die Rechte eines nackten Knaben von sehr gefälliger Bildung erfasst, welcher noch höher auf einer zweiten Stufe dieses Absatzes steht und reisst sie in die Höhe über den Kopf des Knaben hinaus. Die Rechte zückt ein langes Messer gegen ihn. Auch dieser Knabe, dessen Linke flehend in die Höhe gerichtet ist, ist durch eine Beischrift näher bezeichnet. Am linken Arm des Achilleus entlang steht etwas undeutlich, aber doch unzweifelhaft der Name MAPIL. Rechts von diesem Mauerabsatz, der hinten gerade abschliesst, ist die Hälfte eines gerüsteten Kriegers mit Helm, Schild und Lanze sichtbar. Es folgt ein Pfeiler, unten weiss, oben schwarz, welcher durch die ganze Hobe des Streifens hindurchgeht und ihn in zwei Theile theilt. Rechts von denselben zeigen sich wieder die Vordertheile eines Viergespanns, dann ein Krieger in vollständiger Rüstung. Darüber sehen von einer zinnengekrönten Mauer ein behelmter und ein unbehelmter Kopf herab, letzterer auffalend roh."

When I saw the vase (Figs. 1 and 2), which at the time belonged to a private owner in Estoril (Lisbon), only one of the three above mentioned inscriptions had been preserved, namely the one reading $A X I \Lambda \Lambda E Y \Sigma$, obviously referring to the warrior between the horses and the altar.

Troilos only showed his left arm, so that Achilles' gesture had no point. The spear of the warrior behind the altar had been repainted - so 
that it was quite upright -, as had the column in the middle. There was a horse's head on the shelf on the right, which was new and made no sense. The chariot-scene on the shoulder had been left untouched.

The second restoration also showed several layers of painting, which have badly damaged the drawing.

And here begins the second part of the story. Two years after the publication of GVP, in April 1964, Dr. Dietrich von Bothmer, the then chairman of the Department of Greek and Roman Art of the Metropolitan Museum of Art in New York, and, as everyone knows, one of the most outstanding authorities in the field, spent a few days in Lisbon in order to be able to see the Greek vases he knew through my publications. Most of all, he wanted to clean the hydria of the Leagros Group. This he did, with the consent of the owner, but it took a long time until I managed to get good pictures of the vase, taken by a professional photographer, and to send them to him in New York.

I think it is worth quoting a few lines of his reply, dated February 7 , $1966^{4}$ :

"You must admit that there is quite a difference between the old restoration and its real condition. I am very glad to have the record of my labors."

As a matter of fact, now we can see (Figs. 3 and 4) how badly damaged Troilos' figure was, and also that what stood on the shelf on the right was just another helmet (not the head of a horse, which made no sense, as I said above).

At closer inspection, other details emerge, such as that the altar of Apollo is made of black tiles only; that only the lower part of Troilos' body has been preserved; that Achilles' corslet was not painted white, but only had incised lines, as usual; that the column with drawings to the right of the altar was a representation of the walls of Troy; and that the shields of the warriors coming to the rescue of the boy had no devices on them.

Although the Iliad makes only one mention of Troilos (24.257), as being one of the sons Priam lost during the Trojan war, other ancient epics, like the Cypria, already specified that he was killed by Achilles.

\footnotetext{
${ }^{4}$ The cleaning of the vase is duly registered in Beazley, Para, p. 161.
} 
Leaving aside other details of the story (which later became also the subject of a lost tragedy of Sophocles), other ancient sources added that the incident happened on the altar of the sanctuary of Apollo Thymbraios, in the Trojan plain.

To demonstrate how popular the myth became, it should be enough to count the number of vases listed by A. Kossetz-Deissmann in LIMC I, 1.72-95 under the heading "Das Troilusabenteuer", totalling one hundred and fifty-four. Of these, fourteen are concerned with our present subject: the killing of Troilos and the subsequent struggle for his corpse.

Now, out of these examples, only the Lisbon hydria (which is mentioned there under number 362) seems to show Troilos while still alive. The other ones show the struggle for his corpse. That is what can be seen on all the other vases in Attic black figure style: Achilles holding Troilos' head in his left hand, in order to throw it to the Trojan opponents who are coming to rescue the boy. Killing someone within the precinct of a temple was liable to be punished by the gods, as was to happen later.

Nevertheless, examples of Troilos taking refuge on Apollo's altar turn up in other styles, for instance in an Attic red figure cup in Perugia by Onesimus (n. ${ }^{\circ} 370$ in the LIMC catalogue): the boy tries to climb up to the god's altar, but Achilles has already grasped Troilos' hair with his left hand.

More or less contemporaneous with the Lisbon hydria, there is another hydria in the British Museum, also ascribed to the Leagros group, and dated to c. 510 B.C. The general scheme is the same, that is to say, an altar in the middle, Achilles' quadriga on the left and Troian warriors on the right. But here another moment is depicted: Achilles has already killed Troilos, whose corpse is falling on the altar, and he holds the boy's head in his right hand, threatening to throw it at his opponents.

Returning to the Lisbon hydria, we feel sure that here Troilos is still alive, since he is standing on the altar. It seems that Achilles' raised left arm, which seems to reach the circle round the shoulder of the vase, has not yet grasped the boy's hair.

More instances of this part of the story may, of course, turn up at any moment, but the examples quoted above show well enough how popular this part of Troilos' fate had become. This in spite of its absence from the Homeric tradition, which only gives to the young son of Priam the epithet iாтLoxápunৎ ('a warrior who fights from a chariot'). 


\section{Abbreviations}

Beazley, $A B V$

Beazley, Para

Brommer

Campanari

Gerhard

Gurlitt

Jahn

LIMC

Richter-Milne

Rocha Pereira

Rocha Pereira, GVP
Attic Black-Figure Vase-Painters (Oxford 1959)

Paralipomena (Oxford 1971)

Vasenlisten zur griechischen Heldensage (Marburg ${ }^{2} 1960$, ${ }^{3} 1973$ )

Bullettino dell' Istituto di Corrispondenza Archeologica (1834, 234-238)

Vases étrusques et campaniens du Musée Royal de Berlin (1843)

Archaeologische Zeitung (N. F., I, 1868, 84-87)

"Griechische Vasenbilder", Archaeologische Zeitung (III, 1854)

Lexicon Iconographicum Mythologiae Classicae (Zürich und München I, 1, 1981)

Shapes and Names of Athenian Vases (New York, The Metropolitan Museum of Art, 1935)

"Notícia sobre vasos gregos existentes em Portugal. II." Parte", Humanitas (XI-XII, 1959, 18-20)

Greek Vases in Portugal (Coimbra 1962) 


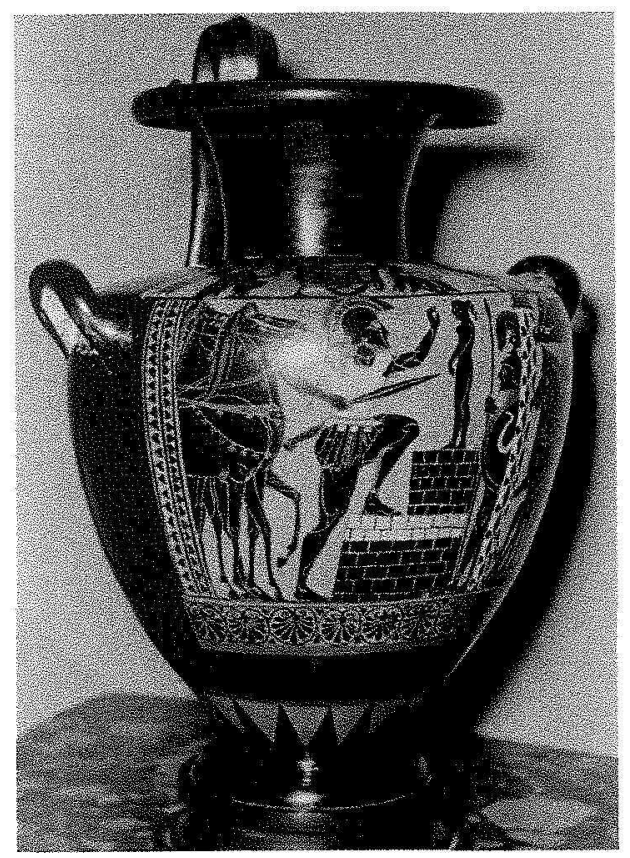

Fig. 1

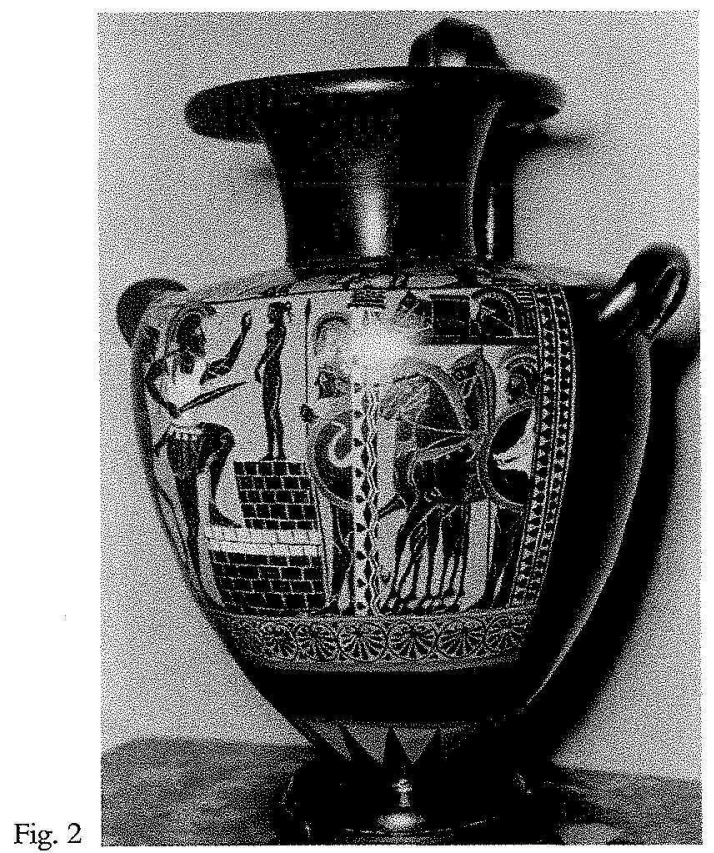




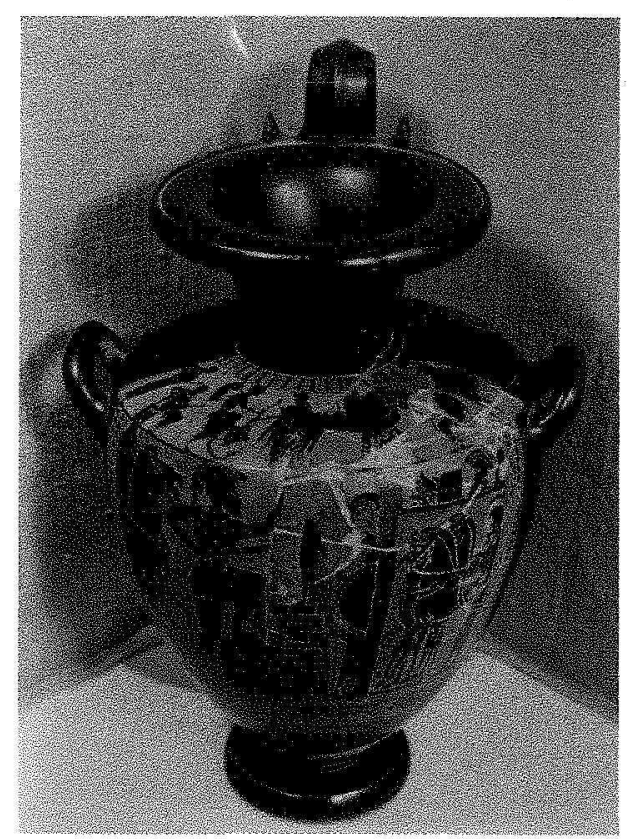

Fig. 3

Fig. 4

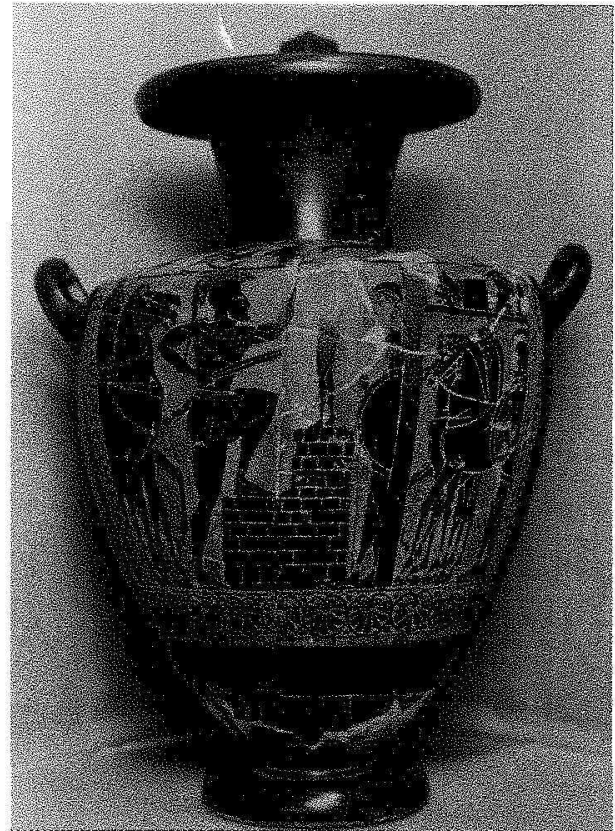

